\title{
Publications ANd Book Reviews
}

M.P. Weitzman, The Syriac Version of the Old Testament, An Introduction (University of Cambridge Oriental Publications 56), Cambridge: Cambridge University Press, 1999. 355 + xiv pp; ISBN 0521632889 (hardback) J50.00 (US\$79.95).

\section{D.J. Lane, Overton CotTage, New Galloway}

The late Michael P. Weitzman has given an excellent statement of his own conclusions with regard to the key topics in OT Peshitta studies. His Introduction is not therefore a manual for beginners which summarises consensus positions, but one which argues with detail for the author's own position. He combines detailed analysis of phrases and words, trenchant criticism of others' theories, imaginative insight into the mind of a Syriac translator, statistical mapping of manuscript relationships, and a sagacious portrayal of likely circumstances for the version's origin and early transmission history. Here is a masterly survey of two centuries of OT Peshitta studies, reviewed in the context of late BCE and early CE Jewish and Christian practice and thought, and of statistics-based text analysis. The author has drawn on detailed studies of the Peshitta of individual books, pointed out the flawed arguments which result when particular findings are extrapolated to universal conclusions or commenced with unexamined, if reasonable, presuppositions.

The Introduction summarises the present state of Peshitta studies; Chapter 2 discusses the relationship between the extant Hebrew and Syriac texts; Chapter 3 the relationship between the Peshitta and other versions; Chapter 4 the homogeneity of the Peshitta as a version; Chapter 5 the background of the Peshitta; Chapter 6 the establishment of the text. This objective and analytic approach enables Weitzman to give, almost as asides, his responses to the questions which are commonplace in Syriac biblical studies, and to criticise conclusions made on the basis of un-examined literary traditions. But, most importantly, the very large number (some 2,000) of quotations of biblical passages and their Peshitta renderings, from the whole range of the OT, enable him to give solutions which are more reliable than those based on evidence from only one biblical book. 
However, Weitzman does take one observation and three working hypotheses as starting points. He rightly points out that the version comes from the Hebrew (Old Testament), and is transmitted solely through the Syriac churches. The hypotheses are: (a) that the version has its origin in a Massoretic text, (b) that the version is homogeneous, translated within a single community (c) the translator has a 'maximalist' rather than 'minimalist' role, matching demands of logic, clarity and religious belief to fidelity to the Hebrew. His evidence, discussion, and conclusions demonstrate these pre-suppositions and observation to be wellfounded. These starting points enable him to take fullest advantage of his extensive and critical knowledge of material relevant to Judaism at the turn of the era, and of textual cruces and their interpretational resolution in the same period.

The reviewer considers that seven questions exercise students of the Peshitta: (a) is the Peshitta dependent on the Massoretic Text, consonantal or vocalised? (b) does it depend upon LXX, either directly or by way of occasional consultation? (c) does it depend on Targum and/or Jewish tradition, whether regarded as text or method? (d) is the version piecemeal, or entire in its construction? (e) when, where, and for whom was it made? (f) does the history of the transmission of the text enable or disable a search for "the original Peshitta"? (g) Is "translation technique" or difference of Vorlage responsible for apparent divergences from MT?

Weitzman answers: (a) The version depends on the sense of the MT, usually in its pointed form: there is no evidence supporting later revision towards MT. (b) LXX has been consulted, more in some books than others, to resolve difficulties presented in MT; there is no evidence of later revision for conformity. (c) Resemblances between Peshitta and a Targum or Jewish tradition indicate a tradition of exegesis not a textual dependence. (d) While there is "...an impressive degree of cohesion between the different books in this biblical version..." biblical books were translated broadly in the Hebrew canonical order, within about 50 years: there is evidence of linguistic change and literary borrowing and referring. (e) Early quotations of Peshitta text, comparison of its language with that of Syriac inscriptions, translation of place and personal names: cumulatively these suggest Osrhoene, even Edessa, as place of origin. Most books were translated about 150 
CE, Ezra/Neh 1-2 Chr about 50 years later. It originated in a nonrabbinic Jewish group whose members after Tatian's mission gradually shifted to Christianity. (f)The present text, the "received text" from the 9th century, as been reliably transmitted for the most part, though the closer proximity to the sense of MT by $5 \mathrm{~b} 1$ and $9 \mathrm{a} 1$ where present shows that inner Syriac corruptions are responsible for variants. (g) Differences between Syriac and Hebrew grammar and syntax, together with the need for clarity and comprehensibility in the target language, explain apparent divergences from MT.

The present reviewer is convinced by his conclusions on the role of MT as Vorlage, on LXX as a consultative document, and of Jewish traditions (some found in Targums) as a defining intellectual climate for Peshitta's exegesis and translation. He would also accept the arguments for a late date and Edessene provenance, and most certainly those for the homogeneity of the Peshitta. But he is not convinced by his arguments concerning a Jewish community whose nature dictated the type of version made. The early history of the Syriac churches (and indeed of non Palestinan Judaism) is more complex than Weitzman allows: the name of Bardaisan as well as Tatian, the presence of such groups as Ebionites in textual and interpretational tradition, the complexities of the St Thomas and Abgar traditions are pointers to this. Weitzman has most valuably pointed the way to further Peshitta debate including political, social, commercial and sectarian elements on and beyond the eastern periphery of the Roman empire rather than ended it.

Again, the range and kind of variants in the Peshitta tradition makes this reviewer reluctant to put them all down to inner Syriac corruption: in Leviticus at least there are variants which correspond to other and equally valid equivalents of MT readings opaque to Syriac translators. Interpretational influence in the transmission as well as the construction process of the version are not fairly to be classified simply as inner Syriac corruption. Finally, while Weitzman is right to emphasise the role of Timothy the Great in the consolidation of Peshitta text tradition, more weight needs to be given to the textual authority of the Upper Monastery in Mosul, which heavily influenced liturgical and NT as well as Peshitta text. Attention needs to be given to the basis as well as the context for text consolidation. 
The volume is a most excellent bequest to the Peshitta world, for the version is demonstrably a world to inhabit rather than merely a text to study. Dr Weitzman has entered the mind of the translator, who has "to be familiar with biblical Hebrew, to apply that knowledge to the understanding of the text, and to express that understanding in Syriac" (p. 95, see also p. 203) The volume's production is admirable, and the use of Hebrew and Syriac and Greek founts excellent (with a curious appearance of East Syriac alphabet words on p. 272); footnotes and indices are well prepared. A comprehensive bibliography containing all the footnote references has, regrettably, not been provided. The real regret, however, is that we cannot now continue the discussion with Michael Weitzman in person, as in the past we did with so much pleasure because of the intellectual courtesy and vivacity with which he presented his detailed and wide-ranging knowledge. 